\title{
Examining children's agency within participatory structures in primary science investigations
}

\begin{abstract}
:
This research examines the use of participatory structures with children in a fourth grade classroom as they engage in an inquiry-based science unit. The dialectical relationship between structure and agency is central to exploring these children's investigation, as children engaged in an investigation designed partly by themselves, in collaboration with their teachers and each other. We consider to what extent participatory structures mediated children's agency in science investigations. Using a combination of ethnographic and design experiment methods, we zoom in on a case study of one child and his collaborative activities with peers, to contextualize the process and underscore the claim that participatory structures created spaces for children to take agency in different ways. Specifically we demonstrate how open-ended structures and participatory curricular design mediated his agentic participation and also transformed the structures of the class, as teachers and students were positioned in new ways.
\end{abstract}

\section{Keywords:}

Agency, structure, dialectics, primary science, participatory structures

Post-refereed, pre-print version of:

Siry, C., Wilmes, S., \& Haus, J. (2016). Examining children's agency within participatory structures in primary science investigations. Learning, Culture and Social Interaction, 10, 4-16

Available at: https://www.sciencedirect.com/science/article/abs/pii/S2210656116000027 


\section{Examining children's agency within participatory structures in primary science investigations}

\section{Introduction}

Bending over his notebook, 10-year-old Leonardo is drawing. He has his head down, and is immersed in work. He is sitting next to another student, Noah. They are supposed to be collaborating on a science investigation together. During the investigation Leonardo acts more or less as an assistant to Noah while following Noah's experiment plan. Noah directs Leonardo at several points during the planning and the execution of the investigation. But Leonardo does not appear to have much interest in carrying out the experiment. In the wholeclass discussion that follows the children's group experiments, Leonardo draws in his notebook. His body is turned towards the notebook lying on the desk and he does not actively take part in the discussion.

"When the students are doing one thing, you can often find Leonardo doing something different ${ }^{1}$," Ms. Nuss ${ }^{2}$ the classroom teacher explains, as we (the authors of this article, and coresearchers in a $4^{\text {th }}$ grade classroom) observe that Leonardo engages in his science investigations in quite unexpected ways. She explains that "he isn't always focused on what everyone should be doing, and he's often doing things that aren't directly related to the task." Ms. Nuss's comment about Leonardo is similar to comments we have heard in a variety of classrooms in our careers, and as former teachers ourselves, we recognize the difficulties that can arise when a student appears to be off-task, distracted, and not engaged in classroom investigations as we might hope. Our discussion with Ms. Nuss regarding Leonardo was prompted by our observation that while participating in open-ended science investigations in his fourth grade class, Leonardo's approach to investigations were sometimes unexpected, and, as Ms. Nuss stated, often very 'different' from the investigative approaches of his classmates.

In this article, we argue that within open-ended classroom structures, Leonardo was able to take agency in a manner that positioned his approach to science as one that enabled him to design an investigation for tackling questions he was exploring. We describe how he pursued his own questions, which were not necessarily aligned with the questions of his peers, or the expectations of the teachers / researchers. He took agency in a manner that afforded his engaging in investigations, and that shifted the structuring of the thematic science unit. We seek to contextualize the role of "agency" as an educational outcome arising from participatory classroom processes (e.g., Doyle, 2015), and three overarching claims emerge from the data analyses:

1. First, open-ended, participatory curricular structures provided spaces for children to engage in the "doing" of science (Siry, Ziegler \& Max, 2012), and through this doing, their ideas and understandings were produced and emerged through agentic investigations.

2. Second, in the taking of agency within open-ended activities, children engaged in science were positioned as resource-rich participants. This provided them with access to differing understandings and perspectives.

3. Third, through the agency / structure relationship, classroom structures were transformed, and students and teacher- researchers were positioned in new ways.

In the sections that follow, these claims are elaborated as we demonstrate ways Leonardo took agency within the context of participatory learning structures. We use these elaborations to illustrate how participatory classroom structures created spaces for Leonardo to engage in meaningful learning despite his unexpected and 'different' approaches.

1 All transcript text has been translated into English by the research team, and cross-checked for accuracy.

2 With the exception of the authors, all participants have been assigned pseudonyms. 


\section{Theoretical Frameworks}

Grounded in cultural sociology (e.g., Bourdieu, 1995; Sewell, 1992) we position teaching and learning as cultural, social acts, and as such, the learning and teaching of science as cultural enactment. Through this perspective, the culture that is science learning is enacted in a dynamic flux, and learning is continually embedded in everyday experiences. Central to the arguments presented in this manuscript is the dialectical relationship between agency and structure, which we elaborate in the next section and then surround in further meaning through the analyses and discussions that follow.

\subsection{Agency $\mid$ Structure}

We consider agency to be the "socioculturally mediated capacity to act" (Ahearn, 2001, p. 112). This framing of agency takes into consideration the choice that is involved in acting, as agency implies the capacity to act, as something that is mediated in social, cultural (and we would add also historical and political) perspectives. Agency is constructed in social practices, and it is negotiated, and renegotiated in interaction (Kumpulainen, Lipponen, Hilppö \& Mikkola, 2014). Our research looks specifically at teachers and students taking agency, and draws relationships to structures that are created to facilitate this. To be more specific, we adopt dialectical perspectives, and as such, we oppose using binaries to make sense of social life. Rather, we work to bring together constructs that are seemingly opposite, and in the dynamic interactions between the two, refine our understandings. Following Roth (2005), we utilize the Sheffer stroke $(\mid)$ to indicate dialectic relationships (agency | structure). The implication for using the Sheffer stroke instead of perhaps a hyphen or a dash is that the neither construct can be the point for understanding the other, but rather, each informs the other (Lund \& Hauge, 2011) and necessitates looking at both.

This understanding of dialectics as recursive, fluid, and dynamic grounds our understanding of agency as dialectically related to the structures that are at play in a given place and time (Sewell, 1992). Structures mediate the agency that a person can (or cannot) take, and in turn, a person's ability to take agency mediates the structures present (Sewell, 1999). These structures are often described as rules and resources (Sewell, 1992), and they can be, for example, material structures such as curricula if we are examining classroom events, or historically constituted structures, such as a teachers' expectation for learning-teaching task completion. This fluid relationship has movement, and through this fluidity the contradictions between agency and structure can lead to reciprocal development (Roth, 2002). In short, through dialectics, the relationship between agency and structure changes through the mediated interaction between the two. As individuals use resources to work towards their goals, they change practices (Tobin, 2012), which can serve to transform structures. In the sections that follow, we seek to unpack the structures that mediated the children's agency (and vice versa) in the context of participatory science investigations. We focus in this analysis on one critical case, Leonardo, to construct an account of what happened when a child is provided with the opportunity to take agency, and does so in differing ways within participatory structures.

\subsection{Participatory science investigations at the primary level}

Our work with children and teachers is around the subject area of science, and in this particular study an 'inquiry-based' science unit was used. The specific curricula we employed engages students in open-inquiry experiences that emerge from students' questions (van Zee, Iwasyk, Kurose, Simpson \& Wild, 2001; Chin, 2004, Gallas, 1995). Relative to more closed forms of science instruction, the use of open-ended participatory structures, in this particular case inquirybased science learning, can contribute to classroom contexts that are culturally, linguistically, and 
cognitively meaningful (Ladson-Billings, 1994; Lemke, 2001; Minner, Levy \& Century, 2010) and thus position students to access resources they bring to the classroom. As explained by Rajala et al. (this issue), open-ended participatory classroom structures provide spaces for students to incorporate their personal knowledge and interest into investigations, and in this way helps them elaborate a personal sense of classroom instruction. Further, Maskiewicz and Winters (2011) found that science inquiry learning environments position students to pursue questions built on their nascent learning resources, and thus contributed to their development of science understanding.

Participatory in this case implies that children are strongly involved in the decision-making process. Students had the opportunity to decide what they wanted to investigate relative to the presented unit of study, and how they would conduct their investigations. We have written elsewhere that a participatory approach to curricula can present a counter-hegemonic force to curriculum documents that frame a subject such as science as rigid and predetermined (Siry, 2013), and drawing on the discussion of structure above, the open-ended investigations from Leonardo's class can thus be framed as participatory classroom structures. These structures will be explored in further detail, as we contextualize them through the analysis and interpretation of specific excerpts from Leonardo's classroom. Specifically, we ask:

1. How do open-ended participatory classroom science tasks structure children's interactions?

2. In what ways did children take agency within participatory curricular structures?

3. What is the relationship between children's agentic moves and the teachers' actions?

\section{Context of this research}

This study was conducted at an urban primary school in Luxembourg City, Luxembourg, which serves approximately 350 children in Kindergarten through grades 6 (4-12 years old). This research was conducted with a class of 16 racially, social-economically, and linguistically diverse fourth grade students (10-11 years old). Luxembourg has a high immigration rate, of approximately 50 percent (MENJE, 2014), and the schools often mirror this diversity. This is particularly relevant for the arguments in this article, as linguistic diversity is a reality of most classrooms, and necessitates providing spaces for flexible dialogue. The curriculum in the primary schools is trilingual, with children learning in Luxembourgish, German, and French. Given the high immigration rate, that means that for a large percentage of children the languages of instruction are not their first-language, which creates a complex linguistic environment in many classrooms.

\subsection{The science curricula}

The open-ended unit used with this class was based on the principles of inquiry-based science instruction (NRC, 1996, 2000). The students, with the guidance of the teacher-researchers, worked through cycles of questioning and investigating toward the goal of building understanding relative to students' questions. These question-investigation cycles, or "inquiry chains" as they are called in the work of Lehrer et al. (2000), are structured so that students first experience open-inquiry investigations (Rezba, Auldridge \& Rhea, 1999) that allow them to pose questions and access their current ideas, understandings, and experiences relative to the subject being considered. From these open-inquiry experiences, students move to more guided experiences designed to build on their understandings. In this way, students are positioned to learn through their questions (van Zee, 2000), the resources they possess (Siry, 2011), and conduct investigations to deepen these understandings.

\subsection{Role as teacher-researchers}


Our role was as both researchers and teachers of the science lessons, as we cotaught in varying configurations with Ms. Nuss. ${ }^{3}$ We distinguish our participation in the science classes by referring to our role as teacher-researchers and Ms. Nuss as the classroom teacher for the sake of clarity and to identify the different positions we held. We also refer to ourselves by our first names throughout the article (Chris, Jana, and Sara).

\subsection{The research approach}

We draw on the research methods of critical ethnography (e.g., Carspecken, 1996) and design experiment (e.g., Brown, 1992). Critical ethnography allows us to look at power and positioning within classroom interactions, and work towards the transformation of classroom structures. Design experiment is appropriate for educational settings, in that what is learned from the research informs the teaching (Brown, 1992). To that end, after each lesson, events were analyzed and interpreted by us, the teacher-researchers, which informed the design of the next lesson. This allowed us to adapt our teaching, our instructional tools, as well as our research, to the specific needs of the group as we interpreted them. A central data source for critical ethnography as well as for design experiment is video- and audio-recording of all science lessons as well as interviews with children during and after the completion of the unit. Through this approach, wholeclass as well as small-group videos were available for analysis. For the claims in this manuscript, we "zoom in" (Roth, 2005) to Leonardo's groups in order to look closely at the role of the openended, participatory tasks as manifested in his work with his peers.

\subsection{The analysis and interpretation of the data}

Following Tobin (2005), we use a layered approach to analysis. Based on our interest in Leonardo, we viewed the corpus of data to identify episodes that emerged from our experiences in the field, the viewing of videos, the analysis of field notes and audio-recorded researcherdiscussions after each of the lessons, as well as a review of interview-transcripts. This allowed us to look for patterns and contradictions within the data, and often led to new perspectives. All episodes that were salient to the research questions were transcribed for further analysis. This emergent approach allowed us to focus on conducting inductive analyses, to create naturalistic (Lincoln and Guba, 1985) accounts of the events of this one particular classroom. The episodes that follow were selected to address the research questions introduced above in section 2.2.

Specifically, we draw on critical case sampling (Patton, 1990 in Lodico, Spaulding, Voegtle, 2010) to narrow our focus throughout the study, as we have zoomed into a case study of Leonardo's interactions with the science investigations, his peers, and his teacher. As such, the episodes that follow all focus on him as we look at how agency can be seen as manifested in his classroom interactions. We weave together analysis with interpretation, in order to contextualize the claims we make. The children were involved in the "doing" of science (Siry, Ziegler \& Max, 2012), and much of their interactions were nonverbal. Thus we use transcript excerpts to represent the spoken word as well as relevant actions of the participants. Furthermore, we include Leonardo's drawn and written representations of his investigations (Brenneman \& Louro, 2008).

\section{The Data - the episodes and their analysis and interpretation}

The science lessons were a part of a five-day sequence of two-hour lessons centered on the water cycle, shown in Figure 1 below. The first lesson began with a mystery based on the water cycle, chosen because of its relevance to key content detailed in the national science curriculum 
(MENJE, 2014). The first day of the unit children shared initial ideas about what was happening in the mystery, and considered ways to investigate the phenomena. Starting with a mystery was intended to position children in a process of posing questions, engaging in dialogue, and subsequently designing investigations to solve the mystery (van Zee, 2000). Students discussed their ideas in pairs, and then worked in groups to elaborate and conduct their investigations. Over the course of the sequence, the students engaged in open investigations driven by their own ideas related to the mystery during the first three days. The last two days the students conducted investigations. This was a purposeful move decided by the teacher and the teacher-researchers to support the synthesis of students' new understandings.

\begin{tabular}{|c|c|c|c|c|c|c|}
\hline $\begin{array}{l}\text { Day of } \\
\text { Instruction }\end{array}$ & Day 1 & Day 2 & Day 3 & Day 4 & Day 5 & Day 6 \\
\hline Episode & 1 & 2 & 3 & 4 & & \\
\hline $\begin{array}{l}\text { Type of } \\
\text { Inquiry }\end{array}$ & $\begin{array}{l}\text { Open-inquiry } \\
\text { investigation }\end{array}$ & $\begin{array}{l}\text { Open-inquiry } \\
\text { investigation }\end{array}$ & $\begin{array}{l}\text { Open-inquiry } \\
\text { investigation }\end{array}$ & $\begin{array}{l}\text { Guided- } \\
\text { inquiry }\end{array}$ & $\begin{array}{c}\text { Direct } \\
\text { instruction }\end{array}$ & \\
\hline $\begin{array}{l}\text { Description } \\
\text { of Activities }\end{array}$ & $\begin{array}{l}\text {-Introduction } \\
\text { to the mystery } \\
\text { story } \\
\text { - Students } \\
\text { generate } \\
\text { questions } \\
\text { about the } \\
\text { mystery } \\
\text { - Students plan } \\
\text { an } \\
\text { investigation in } \\
\text { groups }\end{array}$ & $\begin{array}{l}\text {-Students } \\
\text { conduct their } \\
\text { investigations } \\
\text { in groups }\end{array}$ & $\begin{array}{l}\text { - Students } \\
\text { keep } \\
\text { conducting } \\
\text { their } \\
\text { investigations } \\
\text { in different } \\
\text { groups } \\
\text { - Students } \\
\text { took pictures } \\
\text { of their } \\
\text { investigations }\end{array}$ & $\begin{array}{l}\text { - Students } \\
\text { conduct a } \\
\text { demonstratio } \\
\text { n with ice and } \\
\text { steam }\end{array}$ & $\begin{array}{l}\text { - Teacher } \\
\text { explanation } \\
\text { of the water } \\
\text { cycle }\end{array}$ & $\begin{array}{l}\text {-Group } \\
\text { student } \\
\text { interviews }\end{array}$ \\
\hline
\end{tabular}

Figure 1: Flowchart of the events that took place in the classroom

To illustrate our findings we present four episodes that reveal Leonardo's position at different time points in this sequence of science-focused activities. Each episode is compiled of smaller excerpts to show the unfolding of the classroom events and to discuss the positioning of students and teachers within the classroom structures across the five-day sequence of lessons.

\section{1 Episode 1: Leonardo's question emerges}

To begin the unit, the students read the mystery-story (Konicek-Moran, 2008). The story is about two girls sleeping in a tent, and the 'mystery' emerges in the story when during the night water droplets drip from the top of the inside of the tent. Once the children finished reading the story, we asked them to think about questions or ideas they might have as to why this occurred. After the children each wrote down their questions, we had a group discussion. Leonardo raised his had to share his wondering that Maybe the weather was grey?, which is an expression implying that it was rainy. As we detail in the coming excerpts, Leonardo's wondering about the weather stayed with him throughout the investigations that followed. Once the children shared their first thoughts about the mystery, they discussed their ideas in groups with the goal of deciding on questions that could be investigated through experiments versus those that could be answered through other means (Internet, books, experts, etc.). Chris then called them all together again for a whole group discussion in which each shared one question, part of which is represented in 1.1 below.

\section{Episode 1, Excerpt 1}

$\begin{array}{ll}\text { Line } & \text { speaker } \\ 01 & \text { Chris }\end{array}$

$01 \quad$ Chris

Ok, now we would like to hear some of your questions. (...) we will go around the classroom, and each one of you selects one question, 
which is interesting to you. (...) now, just some example questions right now.

((Leonardo's hand is raised))

02 Chris So Leonardo, lets start with you

03 Leonardo When it is a tsunami and when it also rains really hard, is it dangerous?

04 Chris OH, ok ((goes on to the next child's question))

Chris took all the children's questions in turn through this initial sharing out phase of the unit. At the time, Leonardo's question (line 03) seemed quite off-topic to Chris, and her answer is simply $\mathrm{OH}$, ok (line 04), but she accepted it along with the questions from other students, and moved on to encouraging others to share their questions. In later discussion, the teacher-researchers and the classroom teacher shared their surprise over Leondardo's tsunami question, as it was not aligned with the other groups' questions. Upon later analysis, we find this theme of excessive rain one that continues throughout Leonardo's comments and investigations as a possible 'solution' to the mystery. Participatory approaches to teaching necessitate not commenting with judgment on children's ideas, but rather, acknowledging them, and facilitating their investigation by the children. In this first excerpt, Leonardo's answer was surprising to Chris, and this shaped the relationship between student and teacher-researcher, as both Leonardo and Chris had to adapt to one another. Furthermore, Leonardo was agentic in terms of telling how he thought it rained in the tent, being able to share it with the class, and to persist in working on it, as shown in the next episodes.

After Leonardo asked about a tsunami and hard rain, the other children in turn raised their questions and moved into teacher-selected groups and to begin investigating their questions. When all groups had developed their plans, Chris asked how they would want to investigate their questions. She stressed that their questions might change over the weekend or new ones could come up, and Sara added that they might see something similar to the phenomena in the story. As such, we hoped to make connections between what they were investigating in school and their out-ofschool time. Leonardo raised his hand, and the following interaction occured.

\section{Episode 1, Excerpt 2}

$\begin{array}{ll}\text { line } & \text { speaker } \\ 01 & \text { Chris } \\ 02 & \text { Leonardo } \\ 03 & \text { Sara } \\ 04 & \text { Chris }\end{array}$

Yes, Leonardo?

Are we allowed to also look in the computer to look for ideas? Scientists do that, too.

Yes, scientists do that, too - some questions can be answered better this way. For example your question about the tsunami; that was a great question. Though here, we cannot experiment to investigate this, but maybe you can research this over the weekend and tell us, what you find out.

Leonardo's initial wonderings became clear during the course of the first lesson, represented above in two excerpts. We were not quite sure at the moment of where he was going with his questions about rain and tsunamis, but our role in an open-ended, participatory approach was not to directly guide the process of pursuing questions, but rather to provide the space and support to investigate their questions. We were positioned in a place of uncertainty. At the same time, Leonardo was positioned as knowing where he wanted to take his question, and we needed to trust his pursuing of his ideas as he took agency with a second question and following his thoughts on tsunamis. 


\section{Episode 2: Leonardo as an assistant}

In this episode, the lesson focused on children deciding how to develop the investigation to approach the mystery and their questions. In a whole class introduction, several children raised their hands and shared moments they recalled of camping, water dropping on them, etc. Leonardo raised his hand, and shared that he thought about the story over the weekend and considered that maybe the child in the story camped a few years ago, and it rained hard and the child forgot this when he took the tent out again. Jana clarified, do you mean that he had put the tent away wet? And Leonardo said yes. This short exchange builds upon Leonardo's initial questions and wonderings in episode 1 above, in which he wondered about weather, storms and heavy rain. After this discussion, Jana reminded the children that they planned as a group what they wanted to pursue. She elaborated that now was the time to try out the investigation. The classroom teacher arranged students into new groups. During this time, we circulated to explain that if they had separate plans in their groups, they could choose to do them all, as there was enough time. The resources available to students included basic school science equipment (thermometers, magnifying glasses) and a variety of supplies available in the classroom (containers, warm water, desk lamps, plastic wrap, tape). Students also had access to request additional materials they might need to conduct their investigations.

Leonardo worked with one boy, Noah, and they began to set up the investigation Noah planned. There was little verbal interaction between the two boys during 15 minutes of investigation. Noah was clearly the organizer of the experiment, as he got the supplies, manipulated the materials, and documented what he observed. During this time, Leonardo often watched another group close by, fidgeted in his chair, used his magnifying glass to look around the room, yawned several times, and did not appear to be engaged in the organizing of the experiment.

\begin{tabular}{rll}
\multicolumn{2}{c}{ Episode } & 2, Excerpt 1 \\
line & speaker & \\
01 & Leonardo & Should I do that? \\
02 & Noah & No \\
03 & Leonardo & [inaudible] assistant \\
& & (6 second pause) \\
04 & Noah & [inaudible] are the assistant
\end{tabular}

While there is little verbal exchange in the interaction around this experiment, it is evident that Noah was in charge of this investigation, and he positioned Leonardo as an assistant. He explained to Leonardo what needed to be done (do this like this, and now like that) as Noah was the one manipulating the materials. One of the few times Leonardo actively participated in the investigation was to hold a cup, and in that moment, he had his head in his hand, and hummed and whistled while Noah set up the experiment. At one point Noah wanted to do something with the materials and Leonardo shook his head and said noooooooo but Noah continued. Noah got supplies and continued to set up the experiment, while Leonardo watched the other groups, whistled, and wiggled in his chair. When Noah asked him to do something, Leonardo became momentarily engaged in the experiment, as he looked closely at the phenomena they observed, but his brief comments throughout clearly place the experiment as being Noah's experiment (why are you doing that? You should do this). Considering the use of pronouns can be an analytic tool to examine positioning in interactions, as the use of first person pronouns can locate responsibility for what has been said (Arnold, 2012). Leonardo did not speak from 'we' or from 'I' in this interaction around the investigation at all, with the exception of line 01 above, should I do that? Noah also did not position him to collaborate, and there was no use of 'we' in his spoken word either. 
After the experiment was finished, both boys got their notebooks to document what was done. Leonardo looked at Noah's work multiple times during the 9 minutes in which they documented the investigation. They did not speak to each other during this time. When Noah finished, he went to Jana, who suggested they explain to each other what they documented, as she saw that Noah wrote in his notebook, while Leonardo drew in his. You could explain it to each other, with you [Noah] reading aloud, and then you [Leonardo] showing your drawing to Noah. Noah read what he wrote to Leonardo, who nodded and at the end of the reading nodded again, and then continued to work on his drawing. Leonardo had drawn a diagram (Figure 2) in which he documented the investigation just completed, but he did not show it to Noah. Instead, after reading his aloud, Noah continued to write in his notebook, and there were no further interactions between the two around the experiment.

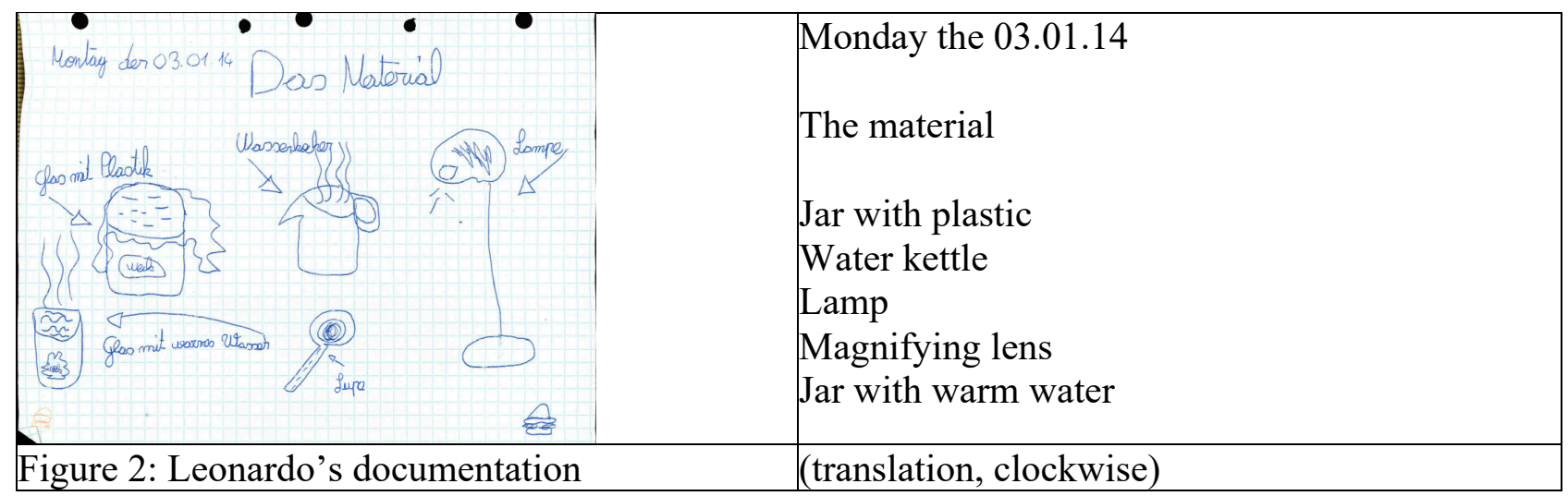

Although he was not actively engaged in conducting this experiment, Leonardo carefully recorded what Noah had organized, and labeled each part of his drawing. His documentation demonstrates that he paid attention to the materials Noah used. After the children returned from recess, Jana told them to continue writing, and to document everything they saw happening in the experiment, and what this might say to working towards solving the mystery. There were ten minutes of writing time at this point. Leonardo quite quickly wrote the first of these two parts (Figure 3, top), and then spent the rest of the time looking around (out the window, to the front of the class, at Noah). He often glanced to the side, and it appears that he was looking at Noah's notes. When Noah was finished, Leonardo returned to his notes and wrote the second part (Figure 3, bottom).

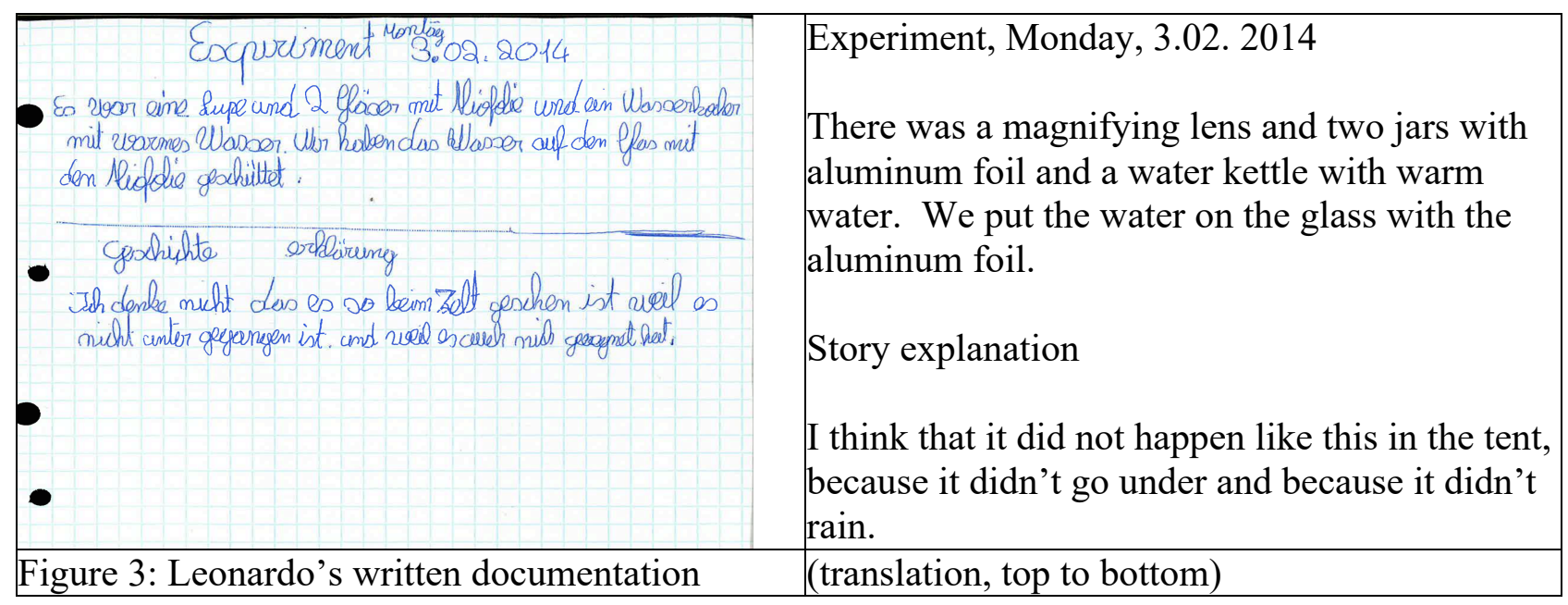


A close look at this document represented as figure 3 reveals several important things relevant for points we are raising in this manuscript. First, is that he wrote two sentences about what was done in the experiment, and he writes with one 'we'. Interestingly, this is not exactly what Noah did, as there was no aluminum foil involved in the experiment. A contradiction emerges here, as it appears he was not tuned into the experiment, yet he did attempt to document the investigation, and also referred to rain again in this documentation.

\section{Episode 3: Leonardo investigates}

This was the second opportunity students had to conduct investigations to explore their questions, and it was similar in structure to the session prior as children worked in groups to implement or adapt their individually-designed plans. The goal was the same as the prior session, to investigate the phenomena related to the tent, and groups were to select a further question to investigate. Leonardo moved to work with two other boys, Francesco and Vlad, and they began by sharing their different plans from the previous day's investigations. Looking at his notes, Francesco turned to the other boys and said, $O K$, what happened? and proceeded to summarize the story that the group had been reading and his own experiment. What experiment did you two do? he asked Vlad and Leonardo. Leonardo looked at his notes, and explained, Ok, we needed a light, and a magnifying lens. Francesco asked some clarifying questions about the light and the magnifying lens, as explained that his group melted the magnifying lens by putting it too close to the light. In this short exchange, both boys were positioned with some expertise on their previous experiments, as they used their notes and drawings to explain what they did. Five minutes into the investigation, Leonardo showed the two boys something from his notes and asked Do you know what this is? and they briefly discussed it. The interaction was interrupted as Chris called the class's attention to say Maybe you have a new prediction? If you have new predictions, write them down. Leonardo got his notebook and began writing, as did the other two boys. At one point in his writing, Leonardo said while writing, I have an idea. OK...I have an idea... and this continues in Episode 3, Excerpt 1, as follows:

\section{Episode 3, Excerpt 1}

line speaker

01 Leonardo I have an idea [inaudible] that the... it came too close

((hand-motioning a wave))

water (..) drops...

((motioning drops with his fingers))

Sara came up to the group to ask about their experiment plans. Leonardo enthusiastically said $I$ have one! and he began to draw and explain to her what his plan was (Figure 4, below). The representation in Figure 4 was constructed while he was talking to Sara, as he drew each of the objects while speaking and explained his idea. This is presented next, in Episode 3, Excerpt 2, which begins with a brief interaction between Leonardo and Sara, as he explained to her his list of material.

In this excerpt Leonardo was working with two different classmates. Within the open-ended participatory classroom structures, there was the space to re-organise the group-members and children were able to work with others. In this structure, Leonardo was able to take agency by choosing to write down his own plan (which he did not do in Episode 2). When Sara questioned him, he became very enthusiastic about writing down and explaining his plan. 


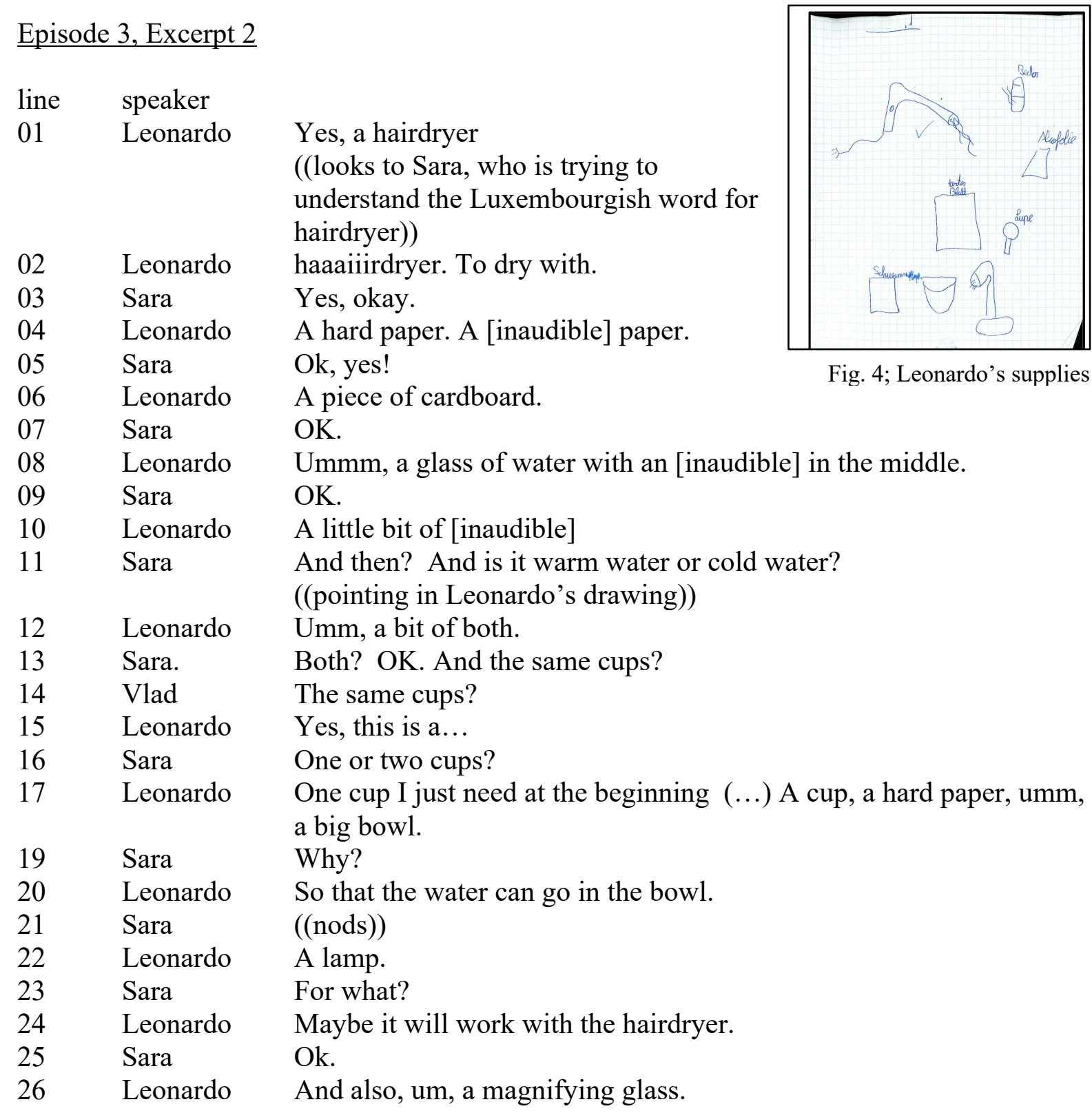

We have chosen to include this longer extract from the data to illustrate Leonardo narrating his plan, as he drew each of the supplies he needed. It seemed a bit unusual to us and Ms. Nuss that he was requesting a hairdryer. The complexities of the multilingual classroom become central here, as it was difficult to know exactly what Leonardo intended to do. He is not always verbally expressive in German or Luxembourgish, and it was not clear to us at the moment why he needed a hairdryer. We had to trust in the open-ended process to provide a structure that would mediate his taking agency to conduct an investigation as he intended. In his narrating to Sara there was a think-aloud opportunity, and his agency was negotiated in this interaction as he was positioned through dialogue to visually represent his plan, albeit one that did not express itself clearly to the teacher or to us. We needed to take a step back, and simply let him work out his experiment. Later we discovered the hairdryer was central to his plan because he was pursuing his initial interest in the possibility of the tent 'crying' due to a storm, and he needed to simulate wind and heat. He continued with his plan even though we did not seem to understand his idea. There was an ownership evident as he drew 
while speaking to Sara and his narrating in Episode 3, Excerpt 2 created a space for him to use drawing for expressing his plan. German is not a first language for Leonardo nor for Sara, and the visual provided a common understanding of his plan. It is important to also emphasize that the "ums" that are in his speaking and the pauses are likely both a production of his talking while drawing and working out his plan, as well as a language issue, as German is his third-language. The names of the objects in Figure 4 were put in later by Francesco, when Leonardo discussed his plan with Francesco and Vlad, and they decided how to move forward on the experiment (Episode 3, Excerpt 3, below). In the interaction with Sara, Episode 3, Excerpt 2, the initial drawn representation was produced, and in the interaction around this representation the boys coconstructed the document (Figure 4). In this excerpt, Leonardo was provided the time to elaborate and explain his plan and the materials to conduct his investigation. He agentically requested material not on our list of provided materials such as a hairdryer.

Leonardo was situated differently in this second episode than he was in the first, as he was working with new children, and as there was the space for him to work out his ideas in drawing and in dialogue with Sara, and to complete his drawing together with Francesco. The open-ended structure of the activities and choosing new partners to work with positioned him to take agency, as he elaborated his own ideas for the experiment. Also, he was positioned to use resources he was familiar with and excited about. In this sense, his resources and position directed the course of inquiry that took place (Maskiewicz \& Winters, 2011). After explaining his plan to Sara, he turned his attention to Vlad and Francesco as they also asked questions about the plan. Each of them had their own plan, and so there was a negotiation that needed to happen for them to determine which experiment would be their joint attempt at this initial point.

\begin{tabular}{|c|c|c|}
\hline line & speaker & \\
\hline 01 & Vlad & $\begin{array}{l}\text { First tell me how the whole thing goes. } \\
\text { ((Leonardo is writing in his binder)) }\end{array}$ \\
\hline 02 & Leonardo & Ok, first, I wanted to [inaudible] and umm, we pour water on it. \\
\hline 03 & Vlad & So pour water on the cardboard? \\
\hline 04 & Leonardo & $\begin{array}{l}\text { Well we take the cardboard, pour water on it, and to dry it we need a } \\
\text { hairdryer, a magnifying lens, and a lamp, and then we can dry it that } \\
\text { way. } \\
\text { ((motions his hand up high above his head and then slowly lowers it)) }\end{array}$ \\
\hline 05 & Francesco & Slow down, that isn't an experiment! I can do that also at home. \\
\hline 06 & Vlad & $\begin{array}{l}((\text { motions Francesco to calm down })) \\
((\text { to Leonardo })) \text { Come on, keep going. }\end{array}$ \\
\hline 07 & Francesco & It isn't an experiment! \\
\hline 08 & Vlad & Come on, explain further. \\
\hline 09 & Leonardo & Aaaand, I will see that it dries. \\
\hline
\end{tabular}

We include this exchange as, in contrast to Episode 2, Excerpt 1 where there was not productive collaborative interaction, Episode 3, Excerpt 3 shows the three boys discussing Leonardo's plan. There was some negotiation that took place as Leonardo explained his plan, Vlad listened and facilitated the explanation (First, tell me how the thing goes, line 01; so pour water on the cardboard? line 03; and Come on, keep going, line 06; and Come on, explain further, line 08) while Francesco pushed him on whether or not his plan is an experiment. Leonardo used the drawn representation to further explain to Francesco his plan, and Francesco wrote the names of the items on the paper. To do that, Francesco first needed to be clear on what was on the drawing, and as Leonardo explained the plan to him, Francesco wrote the words on the paper. The use of 'I' and 
'we' is important in considering this excerpt - Leonardo accepted and shared the responsibility despite Francesco pushing him as to whether or not this was an experiment. Eventually they agree to do Leonardo's experiment.

Figure 5 shows some of the supplies that the boys were using, and Leonardo was holding two key parts - the cardboard pieces of paper, and the hairdryer. Episode 3, Excerpt 3 and Episode 4, Excerpt 1 (on the following page) make reference to the paper, and here it became evident to us that what he was planning was to have two pieces of cardboard together to simulate what he perceives as a tent structure. He had also drawn an image (shown in Figure 6) to show Francesco and Vlad his plan (Figure 4 depicts his material list).

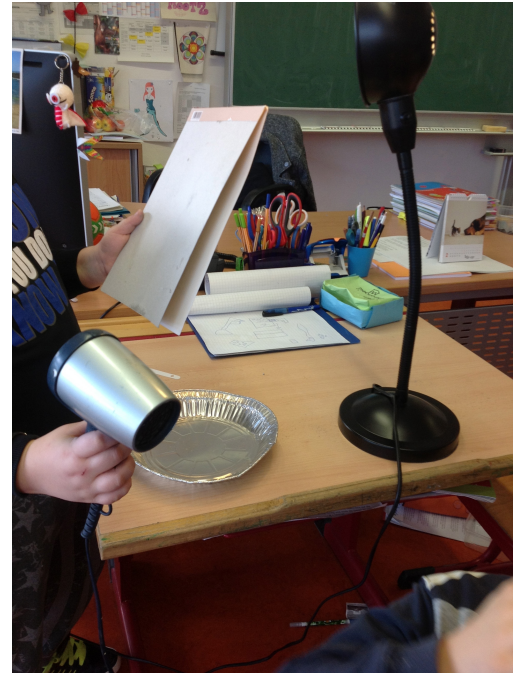

Fig. 5: getting supplies

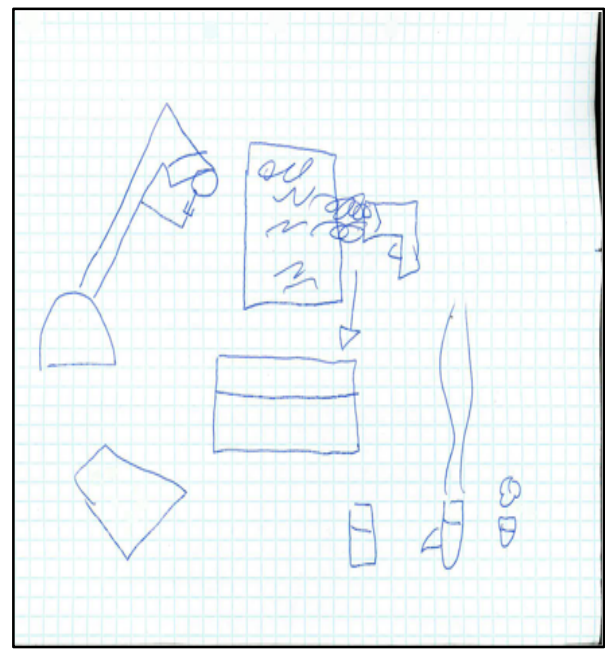

Fig. 6: Leonardo's experiment plan

Despite his initial hesitation (Episode 3, Excerpt 3), once Leonardo explained his idea to Francesco, all three boys became engaged in the experiment. Further, they documented their investigations with photos (e.g., Figure 5), asked questions of each other, and tried a variety of different approaches to Leonardo's plan. Upon seeing the experiment unfold, we had a clearer idea of what Leonardo had been wondering, as they took water and splashed it on the paper (as a storm might) and used the hairdryer on the paper. As he engaged in an open approach to doing science, he took agency to design his experiment, and as such, the structure of the activity of the group changed, as the other boys shifted their approach to work together with him on the hairdryer investigations. Here we see that Leonardo is agentic as he persuades Francesco of his plan and uses the time and space to enact his plan.

\section{Episode 4-Leonardo explains the hairdryer}

The three boys set up and carried out the experiment, and each took on key roles, and negotiated how to move forward on the different steps, as documented by Leonardo in Figure 6. As we watched them use the hairdryer, we still were not sure what he was trying to accomplish. Once the boys carried out a few attempts to investigate with the hairdryer and cardboard, Chris walked up and asked them to share with her what they had been doing.

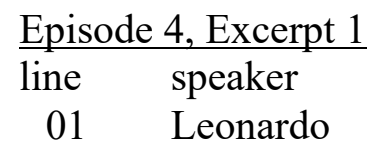

02 Chris
There was a wave, and then it stormed a lot, and then it dried, and then it dropped water a bit. There I, well, if we don't put the dryer on maximum, and the water dries, then it won't function. The hairdryer to you is the storm? 
03 Leonardo Yes, it's the storm.

04 Chris You mentioned before that the water goes somewhere, or do I remember that wrong?

05 Leonardo Once outside and once inside. On the point.

06 Chris Did it happen how you expected?

07 Leonardo Not exactly. It was still wet.

Leonardo was using the hairdryer as the storm, to move the water, which he expected to then end up on the outside and on the inside on the tip of the tent (Once outside and once inside. On the point. line 05). Here he reveals that he is still focused on rain and a storm, and that there was a wave that hit the tent. He shrugged several times while discussing this with Chris, and then she asked if they could do it differently next time.

08 Leonardo I wouldn't put the hairdryer on maximum, and I would put more water on it.

09 Chris Do you think you can say something to the story now? Did you learn something that helps you explain the story?

10 Leonardo The wind, and that the wind dried it. But I went to the internet and it is dangerous when there is a tsunami. I learned that. It was grey and it didn't rain, but it is dangerous. Very dangerous.

Through the process of the investigations he was both able to pursue his investigation, and also, as he states in Episode 4, Excerpt 1, address the initial focus he had related to tsunamis and things like that. In Episode 4, Excerpt 1, Leonardo took agency as he followed through with his tsunami-idea from the questioning-session in Episode 1 to the investigation-phase in Episode 4. The participatory classroom structures allowed the space for this and we teacher-researchers provided space and time for him to conduct his experiment.

\section{Interpretation and Implications}

We began this project with the goal of creating spaces through an inquiry-based curriculum for children to ask their own questions within a science unit. We have presented various episodes to frame the positioning of one child in this study, Leonardo, as he engaged in the open-ended participatory science unit. The data analyses have led to a focus on the episodes presented above, and we make three central claims related to the role of classroom structures that are open-ended and participatory, which we first introduce here and then elaborate next. These are as follows: First, through open-ended structures, he could engage in the doing of science in a way that enabled his agentic participation and supported his investigation of science phenomena (question 1). Second, classroom structures such as a participatory curriculum mediated Leonardo's abilities to take agency, which in turn impacted the structures at play, and teachers and students were positioned in new ways (questions 2 and 3).

\section{Agentic participation and investigation through open-ended structures}

Looking closely at the open-ended structures and their use in the classroom, it becomes evident that these situated Leonardo to be able to act and to choose to engage in different ways, and through this acting he was able to utilize the resources he possessed. His initial question (Episode 1, Excerpt 1) about tsunamis mediated the practices he engaged in during the investigations, and it was a question that stayed with him through working with two different groups of peers. The openended structuring of the science unit began with a shared reading of a text, and then evolved 
through individual reflection, small-group brainstorming, and whole-group discussion, enhanced by student-driven investigations throughout. Interactions between Leonardo and his peers, and between Leonardo and the teacher-researchers, coupled with the open-ended structures enabled for his agentic participation and investigation (including choosing groups to work with, questions to pursue, and materials to use). The process of beginning with student questions coupled with several opportunities for student-driven investigation provided the meditational means for Leonardo to clarify his question for himself, for his peers, and for their investigation. This was a fluid and shifting process, as it can be seen that Leonardo's agency needed to be negotiated through interactions with his peers and with the teacher-researchers. The second peer group interactions structured his carrying out the investigation with the hairdryer to examine his initial storm question. In addition to his verbal expressions of his questions and activities, his written and drawn representations structured his agentic investigations through the interactional support provide by using these representations to explain his ideas and investigations with his peers as well as with the teacher-researchers.

\section{Transformation of structures through participatory curricular design}

Structures can afford, or constrain, agency (Sewell, 1999). In turn, agentic actions can serve to transform structures. Rather than framing this as a static relationship, we see agency $\mid$ structure as fluid, dynamic and recursive. Agency as a construct used in pedagogical settings is intrinsically complex and, as an "educative outcome, is perhaps more elusive and problematic than we usually envision" (Doyle, 2015). Recognizing this complexity, and the elusive notion of agency within classrooms, we consider the goals of the activities as structures, and these shifted and changed as Leonardo worked through the investigations. His initial idea of the tsunami was not aligned with the content goals set for children to reach through the process of developing their investigations. Thus, as Leonardo's agency expanded through the investigations, which we frame as "the actor's capacity to reinterpret and mobilize an array of resources in terms of cultural schemas other than those that initially constituted the array" (Sewell 1992, p. 19), the science unit became transformed for him, and for his two group members. This structuring process included not only the curriculum of what would be investigated, but also the interactions between him and his teacher, and him and his peers, as well with us as teacher-researchers. All these mediated what he was able to do - and when and how he could take agency. Necessary for this mediation within the agency | structure dialect was a sense of flexibility within the open-ended processes, as children could choose their groups to reposition themselves, as Leonardo did in episode 3.

The teaching-space was changed by what Leonardo did, and how he engaged in the process of the open-ended participatory investigations. He was able to elaborate a personal sense of classroom instruction (Rajala and Sannino, 2015) as he incorporated his ideas from outside the context of instruction into his investigations. As such, the teacher-researchers had to shift our roles, and at multiple times in the data we find that we responded to Leonardo with surprise, as Chris did in Episode 1, Excerpt 1 when he suggested a question about tsunamis $(O H, o k)$. As the guiding purpose of the activities was to facilitate open-ended participatory engagement, the teacherresearchers did not jump in to try to redirect him to perhaps more 'appropriate' questions for investigations. Rather, we allowed the space to him and took ours back; we chose not to act, which is also an expression of agency. In this way, the students and teachers were positioned in new ways, and this emerged through the dialectic agency $\mid$ structure relationship. Open-structures provided space for both the student and teacher to engage in interactions and roles that were conceptually outside the 'anticipated'. Using Leonardo as a case example, the students were positioned, and positioned themselves, in ways to take agency to create and conduct investigations of their choosing. In the process of engaging in interactions around a mystery and then collectively deciding 
on investigations to pursue, the positioning of individuals was shifted in the structure $\mid$ agency relationship.

\section{Positioning of teachers and students}

There is a contrast that develops when looking at the two different investigations Leonardo participated in - the one with Noah, and the one with Francesco and Vlad. Leonardo was agentic in a different way in the activity that he developed and then continued to co-construct with Francesco and Vlad than when he was working with Noah on Noah's plan. His interest and engagement with his own investigation was much more evident than in Noah's, and in fact, in Noah's he clearly was positioned as assistant. Open-ended structures created a low-risk environment, in which he was able to pursue his own questions. His initial "wondering" (Siry \& Max, 2013) prompted his investigation, in which he was in control, as he took agency and led his group through pursuing his notion about a storm coming and making the tent wet from the outside. It can also be argued that the open structure of choosing where to sit and who to work with in the second investigation mediated Leonardo's being able to take greater agency and pursue his own experiment. Joining a new group that was open for hearing his ideas and considering them positioned Leonardo to take agency. The interactions between the boys in Episode 3 demonstrate the dynamic interactions in considering Leonardo's question and responding with questions that then mediated the investigation between the three boys. Further, the agency he could take was negotiated, and renegotiated, through his participation. Within the dialectical, dynamic, interplay of structure and agency, Leonardo's science investigations emerged and shifted. Dialectics has been framed as originating in dialogue (Zuss, 2014), and it is evident in the episodes that he constructed his plan through his explanation to Sara as well as his group members. In the spaces created for investigation, Leonardo was able to take agency to not only pursue his original plan, but also to continue his interest in storms and tsunamis. Teachers were also positioned in new ways through Leonardo's agentic participation, in that the teacher-researchers were positioned in a place of uncertainly (see Episode 1, excerpt 2) and thus needed to take a step back for the open-ended processes of the science investigations to unfold within the agency $\mid$ structure dialectic.

\section{Implications for the field}

There are pedagogical and research implications that emerge from this work. First, is the need to create spaces and the time for such classroom transformations to happen. The structure in which these episodes occurred was over multiple lessons, spanning several weeks. Traditionally a topic such as the water cycle would only take a day or two in Ms. Nuss's classroom. By making the time and the space for open-ended participatory structures, room was created for the possible taking of agency by students in their own learning trajectories. The dynamics of this process that were important for the triggering of change in the students' engagement with the mystery. However there are tensions that emerge in working towards such open-ended participatory activities within the institutional structure of schools. We needed to be open to countless different directions that the children could go in. Further, the children needed to trust that we really did not have one "right" way to approach the mystery. This necessitates withholding the need for a lesson to go in a certain direction, which in this case allowed Leonardo to engage in science and take agency. There is a value in holding back, and creating space at multiple levels including pedagogically and interactionally. We were able to see more of what is possible (in terms of learning) if one doesn't push the teacher's plan and is less teacher-centered. We possibly may not have allowed Leonardo to pursue his plan with the hairdryer if we had followed a tighter curriculum frame. 
In addition to our findings as relevant to the field of education and science education, there are implications of this study on the overall for the research field. As researchers we needed to create the space for this to happen in the sense that our particular research foci was emergent from the data resources. Not only did there need to be a flexible curriculum, through the participatory nature of the design, but the research process needed to be open-ended to allow for the dynamics within the agency $\mid$ structure relationship to unfold. As we elaborate in earlier sections of this manuscript, through a design experiment approach, the research and classroom practice emerged together. With an open-ended design, the research focus turned to the unexpected moment in which Leonardo asks about tsunamis, and then examined how this evolved and shifted through the agency | structure relationship. Culture is enacted in patterns and contradictions, which are also dialectically related (Sewell, 1999), and this provided an analytic lens to the research process. Initially Leonardo's comment was a contradiction to the patterns that were expected from the mystery, and examining this through the design experiment process mediated understandings of the role of the open-ended structuring process of the science curricular unit as related to participants' agentic positions. With an open-ended structuring process to the science unit, Leonardo was positioned to draw upon the resources that he brought to the science investigation, within the agency $\mid$ structure relationship, which we have come to perceive as being fluid and moving; what we have called the "dance of agency and structure". 


\section{References}

Ahearn, L.M. (2001). Language and agency. Annual Review of Anthropology, 30, 109-137.

Arnold, J. (2012). Addressing the balance of agency in science classrooms. Unpublished doctoral thesis. Melbourne University.

Bakhtin, M. M. (1981). The dialogic imagination: Four essays by M.M. Bakhtin (M. Holquist, Ed.; C. Emerson \& M. Holquist, Trans.). Austin: University of Texas Press.

Bourdieu, P. (1993). Structures, habitus, practices. In C. Lemert (Ed.), Social theory: The multicultural and classic readings (pp. 479-84). Toronto, Canada: HarperCollins.

Brenneman \& Louro (2008). Science journals in the preschool classroom. Early Childhood Education Journal, 36 (113-119).

Brown, A.L. (1992). Design experiments: Theoretical and methodological challenges in creating complex interventions in classroom settings. The Journal of the Learning Sciences, 2, 114-178.

Carspecken, P. (1996). Critical ethnography in educational research: A theoretical and practical guide. New York: Routledge.

Chin, C. (2004). Students' questions: Fostering a culture of inquisitiveness in science classrooms. School Science Review, 86(314), 107-112.

Doyle, W. (2015). The many faces of agency. Cultural Studies of Science Education, 10(2), DOI $10.1007 / \mathrm{s} 11422-014-9610-3$

Gallas, K. (1995). Talking their way into science. Hearing children's questions and theories, responding with curricula. New York, NY: Teachers College Press.

Gonsalves, A.J., Seiler, G., \& Salter, D.E. (2011). Rethinking resources and hybridity. Cultural Studies of Science Education, 6, 389-399.

Harper, D. (1998). An argument for visual sociology. Jon Prosser (Ed.) Image-based Research: A Sourcebook for Qualitative Researchers. London: Falmer Press, 24-41.

Konicek-Moran, R. (2008). Everyday science mysteries: Stories for inquiry-based science teaching. Arlington, Virginia: NSTA Press.

Kumpulainen, K., Lipponen, L., Hilppö, J. \& Mikkola, A. (2014). Building on the positive in children's lives: A co-participatory study on the social construction of children's sense of agency. Early Child Development and Care, 184 (2), 211-229.

Ladson-Billings, G. (1994). The dreamkeepers: Successful teachers of African American children. San Francisco, CA: Jossey-Bass Publishers.

Lee, O. \& Buxton, C. A. (2013). Integrating science and English proficiency for English language learners. Theory into Practice, 52(1), 36-42.

Lehrer, R., Carpenter, S., Schauble, L., \& Putz, A. (2000). Designing classrooms that support inquiry. In J. M. Minstrell \& E. H. vanZee (Eds.), Inquiring into Inquiry: learning and teaching in science- Part II, (80-99).

Lemke, J.L. (2001). Articulating communities: Sociocultural perspectives on Science Education, Journal of Research in Science Teaching, 38 (3), 296-316.

Lincoln, Y.S., \& Guba, E.G. (1985). Naturalistic inquiry. Newbury Park, CA: Sage Publications.

Lund, A., \& Hauge, T. E. (2011). Designs for teaching and learning in technologyrich learning environments. Nordic Journal of Digital Literacy, 6, (4), 258-272.

Maskiewicz, A.C. \& Winters, V. A. (2011). Understanding the co-construction of inquiry practices: A case study of a responsive teaching environment. Journal of Research in Science Teaching, 49(4), 429-464.

Ministère de l'Education national, de l'Enfance et de la Jeunesse (MENJE). (2014). Les chiffres 
clés de l'Education nationale: statistiques et indicaterus - Année scolaire 2012-2013. [Key

figures of education : Statistics and indicators - school year 2012-2013].

Minner, D., Levy, A., \& Century, J. (2010). Inquiry-based science instruction -What is it and does it matter? Results from a research synthesis, Years 1984 to 2002. Journal of Research in Science Teaching. Vol. 47(4), 474-496.

National Research Council. (2012). A framework for K-12 science education: Practices, crosscutting concepts, and core ideas. Washington, DC: National Academies Press.

National Research Council (1996). National science education standards. Washington, DC: National Academy Press.

Patton, M.Q. (1990). Qualitative evaluation and research methods. Newbury Park, CA: Sage

Pink, S. (2007). Doing visual ethnography. Thousand Oaks, CA: Sage Publications.

Rajala, A., Kumpulainen, K., Lipponen, L., Hilppö, J. \& Rainio, A. (this issue). Student agency and elaboration of personal sense in classroom interactions.

Rajala, A., \& Sannino, A. (2015). Students' deviations from a learning task: An activity-theoretical analysis. International Journal of Educational Research, 70, 31-46

Reddy, M. et al. (1998). Creating scientific communities in the elementary classroom. Portsmouth, NH: Heinemann.

Rezba, R. J., Auldridge, T., \& Rhea, L. (1999). Teaching \& learning the basic science skills. Available online at: www.pen.k12.va.us/VDOE/instruction/TLBSSGuide.doc.

Rogoff, B. (1995). Observing sociocultural activity on three planes: participatory appropriation, guided participation and apprenticeship. In J. V. Wertsch, P., Del Rio, \& A. Alvarez (Eds.), Sociocultural studies of mind (pp. 139-164). USA: Cambridge University Press.

Rogoff, B. (1990). Apprenticeship in thinking: Cognitive development in social context. New York, NY: Oxford University Press.

Rogoff, B. \& Wertsch, J. (Eds.) (1984). Children's learning in the zone of proximal development. New Directions for Child Development, No. 23, San Francisco: Jossey Bass.

Roth, W.-M. (2005). Doing qualitative research: Praxis of method. Rotterdam: Sense Publishers.

Roth, W.-M. (2002). Being and becoming in the classroom. Westport, CT: Ablex/Greenwood.

Roth, W.-M., \& Tobin, K. (2002). At the elbow of another: Learning to teach by coteaching. New York: Peter Lang.

Sewell, W. (1999). The concept(s) of culture. In V.E. Bonell, \& L. Hunt (Eds)., Beyond the cultural turn pp. 35-61). Berkley, CA: University of California Press.

Sewell, W. (1992). A theory of structure: Duality, agency, and transformation. American Journal of Sociology, 98, 1-29.

Siry, C. (2013). Exploring the complexities of children's inquiries in science: Knowledge production through participatory practices. Research in Science Education, 43, 2407-2430.

Siry, C. (2011). Exploring the significance of resource-rich views in science education. Cultural Studies of Science Education, 6 (4), 1019-1029.

Siry, C. and Max. C. (2013). The collective construction of a science unit: Framing curricula as emergent from Kindergarteners' wonderings. Science Education, 97 (6), 878-902.

Siry, C., Ziegler, G., \& Max, C. (2012). "Doing science" through discourse-in-interaction: Young children's science investigations at the early childhood level. Science Education, 96, 311-326.

Stoddart, T., Solís, J.L., Tolbert, S. \& Bravo, M. (2010). A framework for the effective science teaching of English language learners in elementary schools. In D. Sunal, C. Sunal \& E. Wright (Eds.), Teaching science with Hispanic ELLs in K-16 classrooms (Research in science education series). Albany, NY: Information Age Publishing 
Tharp, R. \& Gallimore, R. (1988). Rousing minds to life. Teaching, learning and schooling in social context. New York, NY: Cambridge University Press.

Tobin, K. (2012). Sociocultural perspectives on science education. In B. Fraser, K. Tobin, C. McRobbie (Eds.), Second international handbook of science education (pp. 3-17). The Netherlands: Springer.

Tobin, K. et al. (2005). Improving urban science education. New roles for teachers, students, and researchers. Lanham, ND: Rowman \& Littlefield Publishers.

vanZee, E. H. (2000). Analysis of a student-generated inquiry discussion. International Journal of Science Education, 22, 115-142.

vanZee, E. H., Iwasyk, M., Kurose, A., Simpson, D., \& Wild, J. (2001). Student and teacher questioning during conversation about science. Journal of Research in Science Teaching, 38(2), 159-190.

Wertsch, J. V. (1991). Voices of the Mind: A sociocultural approach to mediated action. Cambridge, MA: Harvard University Press.

Zuss, M. (2014). A dialogue on dialectics. Cultural Studies of Science Education, advance online production, DOI 10.1007/s11422-013-9555-y. 